\title{
PENGARUH PANJANG BATANG DAN BENTUK DAUN EKOR PADA TURBIN ANGIN SUMBU HORIZONTAL DENGAN MEKANISME FURLING TERHADAP PERFORMA TURBIN
}

\section{Basori Hidayatullah}

Mahasiswa

Universitas Negeri Semarang Jurusan Teknik Mesin

basorihidayatullah@students.unnes.ac.id

\section{Dony Hidayat Al-Janan}

Dosen

Universitas Negeri Semarang Jurusan Teknik Mesin aljanan@mail.unnes.ac.id

\section{Danang Dwi Saputro}

Dosen

Universitas Negeri Semarang Jurusan Teknik Mesin

Danangdwisaputro@mail.unnes.ac.id
Small-scale wind turbines that operate at low wind speeds regularly will face yawing performance problems. The purpose of this study was to determine the effect of stem length and tail shape on turbine performance through the power generated and the yawing angle and furling angle that formed. An experimental method was used in this research. Tail stem length variations that used were $0.35 \mathrm{~m}, 0.53 \mathrm{~m}$ and $0.71 \mathrm{~m}$. The tail shape varies Rectangular, Trapezoidal, Triangular, Up Rectangular, Down Rectangular, Up Trapezoidal, Down Trapezoidal, Up Triangular and Down Triangular. Wind speed used in this case is $4.3 \mathrm{~m} / \mathrm{s}, 4.8$ $\mathrm{m} / \mathrm{s}$ and $5.2 \mathrm{~m} / \mathrm{s}$. The tests carried out at Marina Beach, Semarang. Power measurements using a digital multimeter. Yawing and furling angle measurements using video recordings and measured using Solidworks. Wind speed measurements using a digital anemometer. The results showed that the best configuration is the triangular tail shape with $0,53 \mathrm{~m}$ of tail stem length. The power generated of this configuration has increased from wind speed of $4.3 \mathrm{~m} / \mathrm{s}(0.816$ Watt) to $4.8 \mathrm{~m} / \mathrm{s}$ (1.140 Watt) and decreased at a wind speed of $5.2 \mathrm{~m} / \mathrm{s}$ (1.081 Watt). This phenomenon is related to the design where at wind speed above $5 \mathrm{~m} / \mathrm{s}$, the design of furling mechanism will work to reduce the capture of wind energy by diverting the direction of the rotor towards the wind direction. So that the damage of the blade due to higher wind pressure can be minimized.

Keywords: Furling, Horizontal Axis Wind Turbine, Yawing, Tail Stem Length, Tail Shape.

\section{PENDAHULUAN}

Konsumsi energi di Indonesia semakin hari semakin meningkat bersamaan dengan semakin berkurangnya sumber energi tidak terbarukan yang sekarang umum dipakai. Ukuran bumi terbatas dan tidak ada isinya yang tidak terbatas, kecuali sinar matahari, energi dari matahari, energi selain dari bumi [1]. Perlu adanya alternatif pengganti energi lain untuk menanggulangi permasalahan ini. Salah satu energi yang sudah dimanfaatkan dan dikembangkan saat ini adalah energi angin. Energi angin sendiri pemanfaatanya masih cenderung sedikit, dengan potensi tenaga angin yang ada di Indonesia. Pemanfaatan energi angin dan hybrid di Indonesia masih sekitar 3,1 MW dengan kecepatan angin rata-rata 3-6 m/s[2].

Pada Tahun 2018 telah dibangun first wind farm di Indonesia, yaitu PLTB Sidrap I, pada bulan Juli 2018. Wind farm ini mampu menghasilkan 75 MW listrik dan dialirkan ke 70.000 rumah tangga di Sulawesi Utara. Proyek lainnya yaitu Karaha Unit I (30 MW) di Jawa Barat dan Sarulla Unit III (110 MW) di Sumatera Selatan [3].

Turbin angin sumbu horizontal merupakan salah satu jenis turbin angin yang bisa dimanfaatkan sebagai alternatif. Turbin angin Savonius yang termasuk turbin angin sumbu vertikal mampu berputar pada kecepatan angin rendah, namun performa turbin angin Savonius lebih rendah jika dibandingkan dengan turbin angin 
tipe propeller yang memiliki sumbu poros horizontal [4]. Turbin angin yang menghasilkan daya $10 \mathrm{~kW}$ kebawah disebut dengan turbin angin skala mikro, sedangkan yang menghasilkan daya 1,5 hingga 5 MW disebut dengan turbin angin skala besar[5]. Turbin angin skala mikro yang beroperasi pada kecepatan angin rendah secara teratur akan menghadapi permasalahan kinerja yawing atau gerakan horizontal karena sifat dari angin yang tidak rata. Gaya dorong mengenai titik tengah dari sumbu rotor, jika terdapat jarak atau pergeseran dari sumbu yaw maka akan menimbulkan momen yaw [6]. Rotor yang menoleh dari arah angin kurang efisien jika dibandingkan dengan rotor yang tidak menoleh dari arah angin, maka perlu dipertimbangkan efisiensi untuk tujuan produksi energi. Rakitan ekor digunakan untuk memastikan ekstraksi potensi angin secara maksimum meskipun pada kondisi kecepatan angin yang rendah [7]. Ekor turbin pada turbin angin skala kecil difungsikan untuk mengubah arah dan mengakomodasi variasi arah angin yang datang. Ekor diperlukan untuk menghasilkan respon yang cepat dan stabil sesuai dengan perubahan arah angin dan membuat turbin angin skala kecil menghadap ke arah angina [8]. Kecepatan angin yang sangat fluktuatif juga akan mengakibatkan keterbatasan dari kemampuan turbin angin itu sendiri. Pada kondisi kecepatan angin diatas kecepatan angin rancangan, putaran atau rpm sudu dan generator akan melebihi putaran rancangan, sehingga terjadi overspeed [9]. Perlindungan dilakukan untuk mencegah terjadinya overspeed. Karena tanpa adanya sistem perlindungan, akan terjadi kegagalan fungsi, dan mengakibatkan kerusakan pada turbin [10]. Diperlukan adanya mekanisme yang bisa mengatur kemampuan yawing dari turbin sehingga bisa memaksimalkan hasil konversi angin dan meminimalisir kerusakan pada alternator dan dioda yang overheat, dan juga bilah yang overspeed [11]. Mekanisme furling ini sendiri merupakan mekanisme yang dominan untuk mengatasi permasalahan overspeed dan juga kontrol daya pada turbin angin skala kecil [12], meskipun furling sendiri memiliki kemampuan yang buruk dalam menangkap energi saat kecepatan angin tinggi [13].

Penelitian ini bertujuan untuk mengetahui pengaruh dari variasi panjang batang ekor $(0,35 \mathrm{~m}, 0,53 \mathrm{~m}$, dan $0,71 \mathrm{~m}$ ) dan variasi bentuk daun ekor (rectangular, triangular, trapezoidal, upward rectangular, downward rectangular, upward triangular, downward triangular, upward trapezoidal dan downward trapezoidal) terhadap performa turbin yang mengacu pada daya keluaran dan juga performa dari ekor turbin yaitu sudut yawing dan sudut furling yang terbentuk. Hasil dari penelitian ini diharapkan mampu menjadi acuan untuk pengembangan optimasi turbin angin skala kecil dengan mengoptimalkan penangkapan energi oleh turbin.

\section{METODE DAN BAHAN}

Desain penelitian ini menggunakan metode penelitian eksperimen. Metode penelitian eksperimen bertujuan untuk menyelidiki dan menguji kemungkinan sebab akibat dari variabel - variabel yang ditentukan dan membandingkan hasilnya dengan sesuatu atau lebih kelompok kontrol [14].

\subsection{Variabel Penelitian}

Terdapat 3 variabel dalam sebuah penelitian kuantitatif yang dilihat dari peran dan posisinya [14]. Variabel penelitian tersebut terdiri dari variabel bebas yaitu panjang batang ekor dan bentuk daun ekor, variabel terikat adalah daya keluaran, sudut furling dan sudut yawing, dan variabel kontrolnya adalah kecepatan angin.

\subsection{Spesifikasi Rancangan Bilah dan Ekor}

Bilah NACA 3612 dengan jenis taper berjumlah 3 dengan diameter $70 \mathrm{~cm}$ sesuai dengan Gambar 1 .

(a)

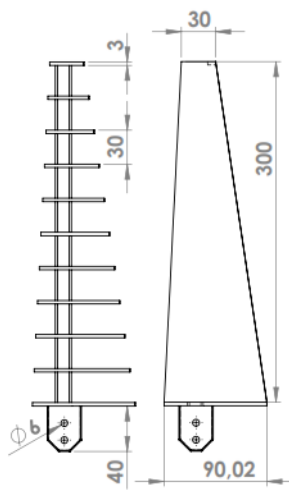

(b)

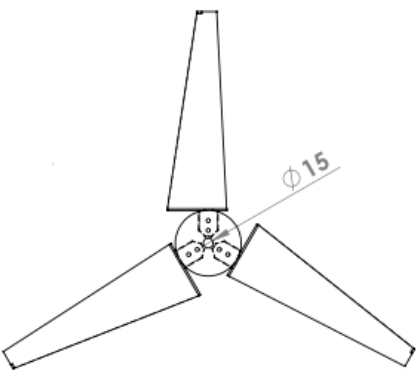

Gambar 1: Bilah taper NACA 3612, (a) bilah taper metode rangka, (b) assembly bilah dengan hub. 
Batang ekor menggunakan bahan pipa aluminium dengan diameter luar $8 \mathrm{~mm}$ dan ketebalan $0,5 \mathrm{~mm}$. Variasi panjang batang ekor adalah $110,35 \mathrm{~m}(0,5 \mathrm{x}$ diameter bilah[9]), 12 0,53 $\mathrm{m}((11+13) / 2)$, dan 13 0,71 m.

Mekanisme furling dapat dirancang dengan menentukan parameter - parameter yaitu vane force, thrust force, moment thrust, length of tail, mass of tail, dan furl force [15]. Dalam penelitian ini ditentukan kecepatan angin rancangan adalah $5 \mathrm{~m} / \mathrm{s}$ dan TSR 7. Rumus perancangan sebagai berikut:

Rotor offset $\left(l_{\text {ofset }}\right)$, panjang offset minimum adalah sebesar 4\% dari diameter sapuan bilah [9].

$$
l_{\text {offset }}=\frac{4 \times D}{100}
$$

D adalah diameter bilah.

Luas sapuan bilah $\left(A_{\text {swept }}\right)$, diketahui dengan menggunakan rumus luas lingkaran.

$$
A_{\text {swept }}=\frac{1}{4} \times \pi \times D^{2}
$$

Gaya dorong $\left(F_{\text {thrust }}\right)$, merupakan gaya dorong yang mengenai rotor.

$$
F_{\text {thrust }}=\rho \times A_{\text {swept }} \times C_{t} \times V_{f}^{2}
$$

Dimana, $\rho$ adalah massa jenis udara $\left(1,225 \mathrm{~kg} / \mathrm{m}^{3}\right), V_{f}$ adalah kecepatan angin rancangan $(\mathrm{m} / \mathrm{s})$, dan $C_{t}$ adalah koefisien thrust. $C_{t}$ untuk TSR 7 adalah $0,9[13]$.

Moment Thrust $\left(M_{T}\right)$, momen timbul akibat jarak antara rotor axis dengan yaw axis.

$$
M_{\text {thrust }}=F_{\text {thrust }} \times l_{\text {offset }}
$$

Luas daun ekor $\left(A_{\text {vane }}\right)$, luas daun ekor adalah $10 \%$ dari luas sapuan bilah [15].

$$
A_{\text {vane }}=\frac{10 \times A_{\text {swept }}}{100}
$$

Gaya dorong pada daun ekor $\left(F_{\text {vane }}\right)$, untuk menghadapkan rotor selalu kearah angin diperlukan pembelokan sebesar $\alpha$. Dalam hal ini $\alpha$ yang digunakan sebesar $20^{\circ}[15]$.

$$
F_{\text {vane }}=\rho \times A_{\text {vane }} \times V_{f}^{2} \times \sin \alpha
$$

Panjang ekor $\left(l_{\text {tail }}\right)$, dengan $M_{\text {restoring }}$ sama dengan $M_{\text {thrust }}$.

$$
l_{\text {tail }}=\frac{M_{\text {restoring }}}{F_{\text {vane }}}
$$

Massa pada ujung ekor $(m)$, untuk keseimbangan momen pada sumbu pivot, maka $F_{g}=F_{\text {vane }}$. Digunakan mekanisme inclined pivot axis untuk mempertahankan posisi ekor dengan memiringkan sumbu engsel sebesar $15^{\circ}$ terhadap yaw axis [6].

$$
F_{g}=m \times g \times \sin \theta
$$

Dimana, g adalah gaya gravitasi $\left(9,81 \mathrm{~m} / \mathrm{s}^{2}\right)$, dan $\theta$ adalah sudut kemiringan pivot.

Panjang batang ekor $\left(l_{\text {boom }}\right)$, dengan panjang batang pivot adalah $0,08 \mathrm{~m}$.

$$
\begin{aligned}
& X=l_{\text {pivot }} \times \sin \theta \\
& l_{\text {boom }}=l_{\text {tail }}-X
\end{aligned}
$$

Dimana, $l_{\text {pivot }}$ adalah panjang batang pivot. 


\subsection{Diagram Alir Penelitian}

Penelitian ini mengamati tentang performa turbin angin dari pengaruh perbedaan bentuk daun ekor dan juga panjang batang ekor pada turbin angin. Pengamatan yang dilakukan dalam penelitian ini meliputi pengamatan terhadap arus dan tegangan yang diukur dari motor atau generator pada kecepatan angin yang sudah ditentukan, yaitu pada kecepatan angin $4,3 \mathrm{~m} / \mathrm{s}, 4,8 \mathrm{~m} / \mathrm{s}$ dan $5,2 \mathrm{~m} / \mathrm{s}$. Diagram alir penelitian sesuai dengan Gambar 2.

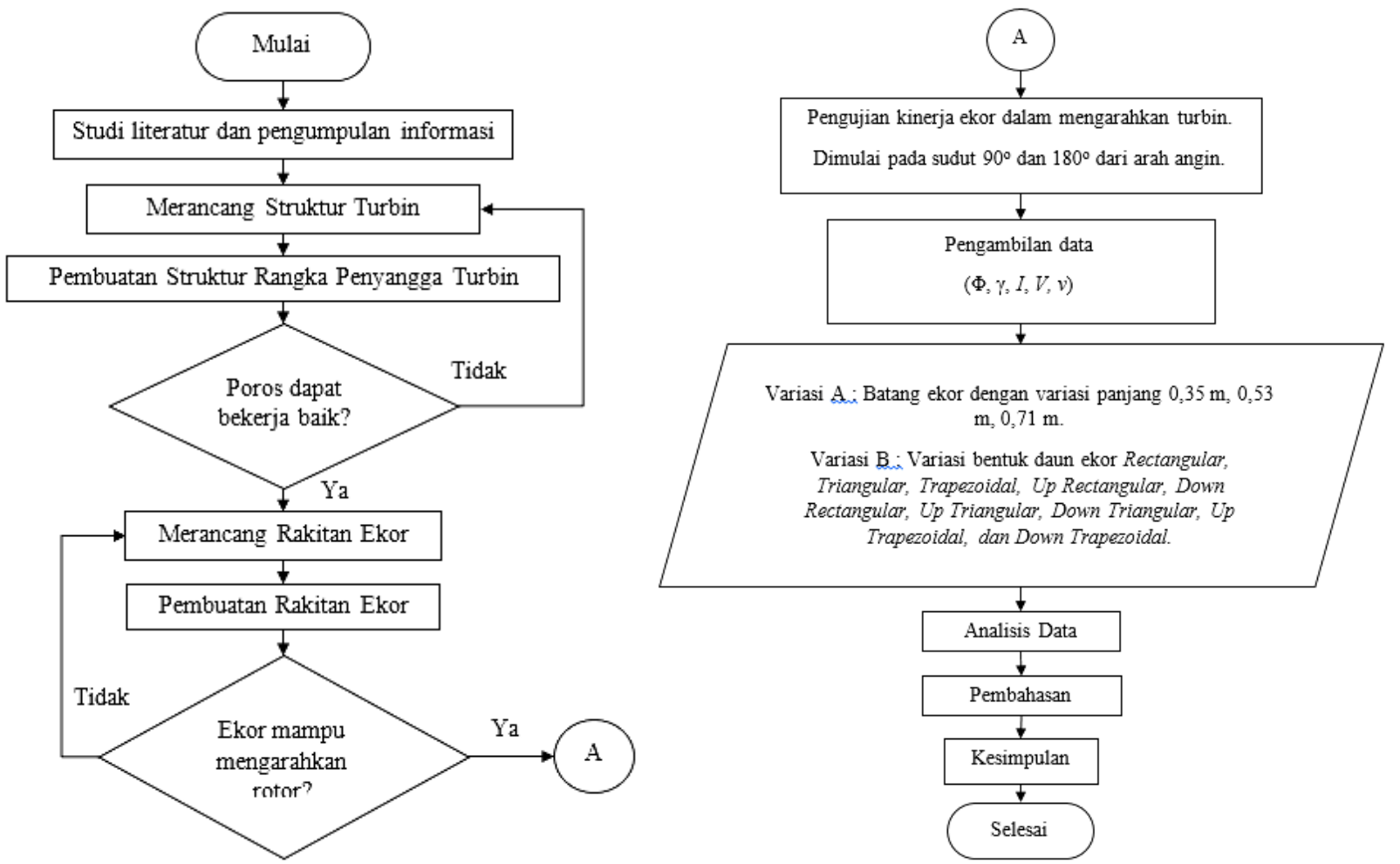

Gambar 2: Diagram Alir Penelitian

Tabel 1: Data Hasil Perhitungan Rancangan

\begin{tabular}{c|c|c}
\hline SIMBOL & NILAI & SATUAN \\
\hline$V_{f}$ & 5.00 & $\mathrm{~m} / \mathrm{s}$ \\
\hline$D$ & 0.70 & $\mathrm{M}$ \\
\hline$P$ & 1.23 & $\mathrm{~kg} / \mathrm{m} 3$ \\
\hline$G$ & 9.81 & $\mathrm{~m} / \mathrm{s} 2$ \\
\hline$C_{t}$ & 0.90 & - \\
\hline$A_{\text {swept }}$ & 0.38 & $\mathrm{~m} 2$ \\
\hline$l_{\text {offset }}$ & 0.28 & $\mathrm{M}$ \\
\hline$F_{\text {Thrust }}$ & 10.60 & $\mathrm{~N}$ \\
\hline$M_{T}$ & 0.29 & $\mathrm{~N} . \mathrm{m}$ \\
\hline$A_{\text {vane }}$ & 0.04 & $\mathrm{~m} 2$ \\
\hline$A$ & 20.0 & $\mathrm{deg}$. \\
\hline$M_{\text {restoring }}$ & 0.29 & $\mathrm{~N} . \mathrm{m}$ \\
\hline$F_{\text {vane }}$ & 0.40 & $\mathrm{~N}$ \\
\hline$l_{\text {tail }}$ & 0.73 & $\mathrm{~m}$ \\
\hline$l_{\text {pivot }}$ & 0.08 & $\mathrm{~m}$ \\
\hline$\Theta$ & 15.0 & $\mathrm{deg}$. \\
\hline$x_{\text {boom }}$ & 0.02 & $\mathrm{~m}$ \\
\hline & &
\end{tabular}




\begin{tabular}{c|c|c}
\hline lboom $1,2,3$ & $0.71,0.53,0.35$ & $\mathrm{~m}$ \\
\hline$M_{\text {vane } 1,2,3}$ & $0.28,0.21,0.14$ & $\mathrm{~N} . \mathrm{m}$ \\
\hline$M_{\text {weight } 1,2,3}$ & $0.28,0.21,0.14$ & $\mathrm{~N} . \mathrm{m}$ \\
\hline$F_{g}$ & 0.40 & $\mathrm{~N}$ \\
\hline$M_{1}$ & 0.15 & $\mathrm{Kg}$ \\
\hline
\end{tabular}

\subsection{Skema Alat Pengujian}

Skema alat pengujian dan turbin yang digunakan dalam penelitian ini ditunjukkan pada Gambar 3 .

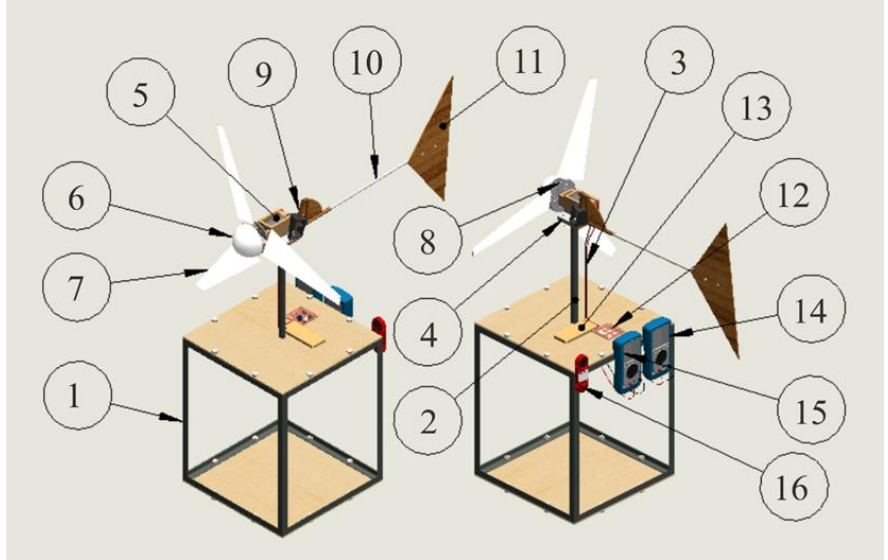

Gambar 3: Skema alat pengujian

Keterangan Gambar 3:

1. Rangka penyangga turbin

5. DC Generator

6. Cone

2. Tiang turbin

7. Bilah (blade)

8. Hub bilah
9. Sambungan ekor

10. Batang ekor

11. Daun ekor

12. Rangkaian PCB
13. Handphone

14. Multimeter 1

15. Multimeter 2

16. Anemometer

\subsection{Mekanisme Furling}

Furling merupakan sebuah mekanisme yang digunakan untuk memberikan keamanan terhadap turbin apabila kecepatan angin mencapai kecepatan yang sangat tinggi dan akan membahayakan turbin angina [6]. Furling dalam penelitian ini ditujukan untuk mengoptimalkan kinerja dari turbin angin dalam penangkapan energi dan sebagai metode pengamanan terhadap kerusakan bilah yang mungkin terjadi. Yawing terjadi pada poros utama sedangkan furling terjadi pada poros pivot. Mekanisme furling yang akan bekerja pada penelitian ini seperti skema pada Gambar 4.
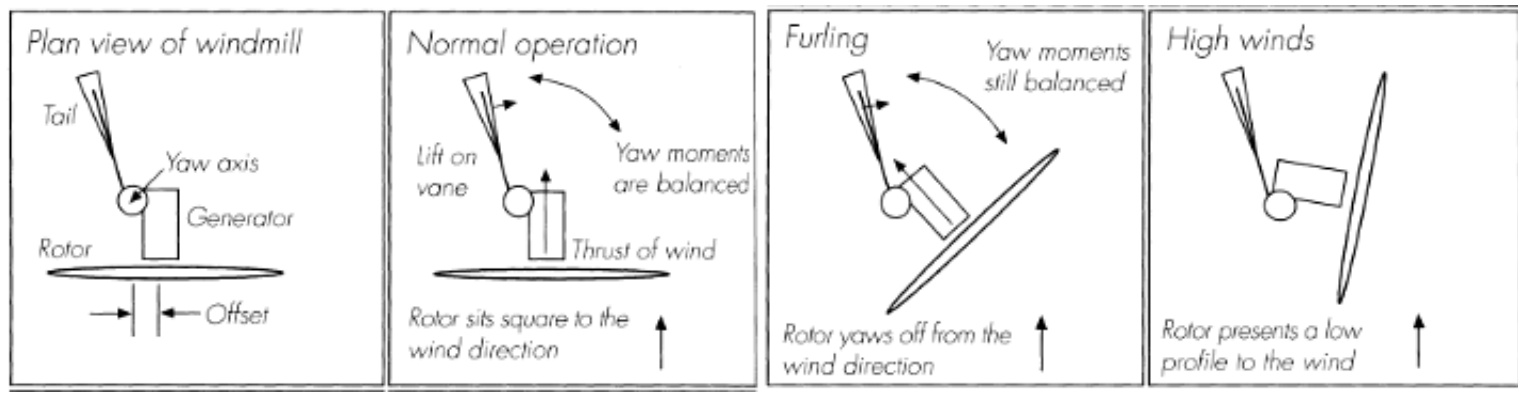

Gambar 4: Konsep mekanisme furling dan yawing [6]. 


\subsection{Alat dan Bahan}

Adapun alat yang digunakan yaitu anemometer digital Benetech tipe GM816 untuk mengukur kecepatan angin, multimeter AC/DC voltage tester Richmeter RM101 untuk mengukur tegangan dan arus yang dihasilkan dalam penelitian, Laptop Acer Aspire 4739 untuk mendesain ekor, mengukur sudut furling dan juga sudut yawing, Handphone untuk merekam data penelitian, DC motor Canon FH-71860 digunakan sebagai alat konversi dari putaran menjadi energi listrik. Adapun bahan penelitian yang digunakan yaitu Triplek dengan ketebalan $3 \mathrm{~mm}$ untuk daun ekor, Pipa aluminium dengan diameter luar $8 \mathrm{~mm}$ untuk batang ekor, Mur dan Baut untuk menggabungkan batang ekor dengan daun ekor.

\section{HASIL DAN DISKUSI}

Dalam rancangan ekor ini diinginkan sudut furling dan yawing akan mulai terbentuk pada kecepatan angin 5 $\mathrm{m} / \mathrm{s}$ dan mampu mengurangi penangkapan angin dengan membelokan rotor menjauh dari arah angin. Hal ini berhubungan dengan daya yang dihasilkan karena dengan semakin tinggi sudut furling dan sudut yawing yang terbentuk maka daya yang dihasilkan akan menurun, namun disisi lain untuk pengaman dari kerusakan sudu, maka harus adanya rancangan ekor untuk sistem ini. Kecepatan angin yang diambil sebagai acuan pada penelitian ini yaitu pada kecepatan angin $4,3 \mathrm{~m} / \mathrm{s}, 4,8 \mathrm{~m} / \mathrm{s}$ dan $5,2 \mathrm{~m} / \mathrm{s}$. Dari data yang didapatkan menunjukkan bahwa pada kecepatan $4,3 \mathrm{~m} / \mathrm{s}$ sudut furling dan sudut yawing sudah terbentuk. Pengambilan data dilakukan sesuai dengan skema seperti Gambar 5.

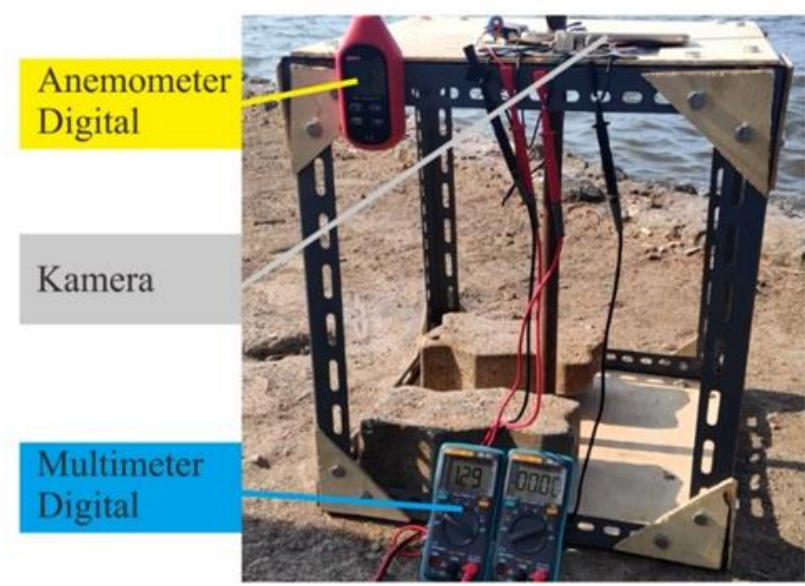

Gambar 5: Pengambilan data

Seiring panjang batang yang semakin panjang, maka sudut furling dan yawing yang terbentuk semakin kecil. Ini berdampak pada daya tangkap angin oleh sudu turbin. Bentuk daun ekor juga sangat berpengaruh untuk mengarahkan angin, karena faktor dari bentuk daun ekor yang memiliki geometri yang berbeda meskipun luas area dari masing - masing bentuk sama.

\subsection{Pembahasan}

Hasil daya keluaran dari penelitian ini berdasar panjang batang ekor ditunjukkan pada Tabel 2, Tabel 3 dan Tabel 4.

Tabel 2 menunjukkan pada panjang batang 0,35 m, pada kecepatan angin 4,3 m/s daya keluaran terbesar terdapat pada bentuk daun ekor jenis Triangular dengan nilai 0,991 watt, dan daya keluaran terkecil terdapat pada bentuk daun ekor jenis Up Rectangular dengan nilai 0,443 watt. Pada kecepatan angin 4,8 m/s daya keluaran terbesar terdapat pada bentuk daun ekor Triangular dengan nilai 1,008 watt, dan daya keluaran terkecil terdapat pada bentuk daun ekor Trapezoidal dengan nilai 0,666 watt. Pada kecepatan angin 5,2 m/s daya keluaran terbesar terdapat pada bentuk daun ekor Up Rectangular dengan nilai 1,087 watt, dan daya keluaran terkecil terdapat pada bentuk daun ekor Trapezoidal dengan nilai 0,799 watt. 
Tabel 2. Daya keluaran pada panjang ekor $0,35 \mathrm{~m}$

\begin{tabular}{|c|c|c|c|c|c|}
\hline \multirow{2}{*}{ Bentuk daun ekor } & Kecepatan angin & \multirow{2}{*}{ Bentuk daun ekor } & Kecepatan angin & \multirow{2}{*}{ Bentuk daun ekor } & \multirow{2}{*}{\begin{tabular}{|c|} 
Kecepatan angin \\
$5,2 \mathrm{~m} / \mathrm{s}$
\end{tabular}} \\
\hline & $4,3 \mathrm{~m} / \mathrm{s}$ & & $4,8 \mathrm{~m} / \mathrm{s}$ & & \\
\hline Triangular & 0,991 & Triangular & 1,008 & Up Rectangular & 1,087 \\
\hline Down Triangular & 0,817 & Up Trapezoidal & 0,906 & Up Triangular & 1,078 \\
\hline Up Trapezoidal & 0,783 & Rectangular & 0,891 & Down Rectangular & 1,070 \\
\hline Down Rectangular & 0,776 & Down Triangular & 0,823 & Up Trapezoidal & 1,047 \\
\hline Down Trapezoidal & 0,704 & Down Rectangular & 0,818 & Down Triangular & 1,043 \\
\hline Rectangular & 0,660 & Up Triangular & 0,809 & Triangular & 1,018 \\
\hline Trapezoidal & 0,554 & Up Rectangular & 0,804 & Rectangular & 1,003 \\
\hline Up Triangular & 0,466 & Down Trapezoidal & 0,793 & Down Trapezoidal & 0,981 \\
\hline Up Rectangular & 0,443 & Trapezoidal & 0,666 & Trapezoidal & 0,799 \\
\hline
\end{tabular}

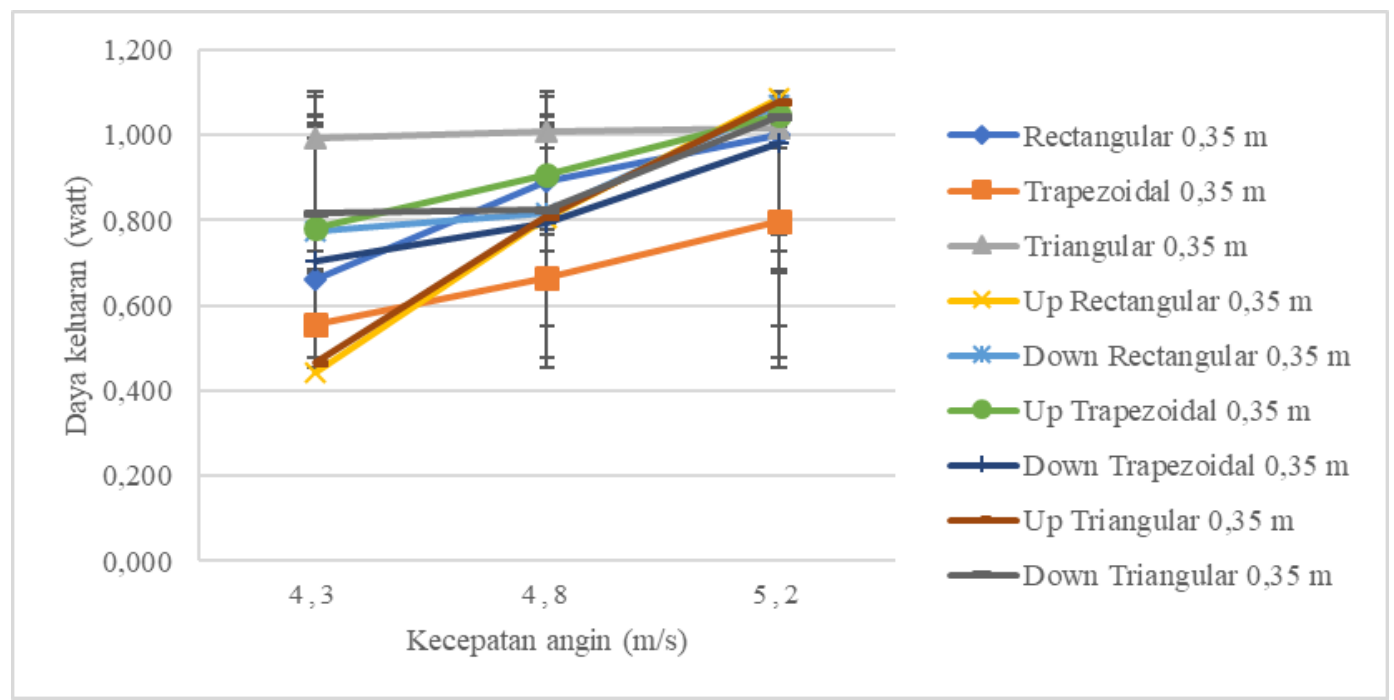

Gambar 6: Hubungan daya keluaran terhadap kecepatan angin $(0,35 \mathrm{~m})$.

Gambar 6 menunjukkan pada panjang batang 0,35 m ini, semua variasi bentuk daun ekor dari kecepatan angin 4,3 m/s ke 5,2 m/s terus mengalami kenaikan daya keluaran. Hal ini terjadi dikarenakan adanya pengaruh dari panjang batang ekor yang terlalu pendek sehingga kondisi ekor yang kurang stabil dalam mengarahkan turbin yang disebabkan momen dorong dengan momen balik pada ekor tidak seimbang, sehingga penangkapan angin oleh turbin menjadi naik dan turun dengan tempo yang sangat cepat dan menyebabkan mekanisme furling yang telah dirancang tidak bisa bekerja maksimal.

Tabel 3: Daya keluaran pada panjang ekor $0,53 \mathrm{~m}$

\begin{tabular}{|l|r|}
\hline \multirow{2}{*}{ Bentuk daun ekor } & Kecepatan angin \\
\cline { 2 - 2 } & $\mathbf{4 , 3} \mathbf{~} / \mathbf{s}$ \\
\hline Triangular & 0,816 \\
\hline Up Rectangular & 0,787 \\
\hline Rectangular & 0,737 \\
\hline Up Triangular & 0,732 \\
\hline Up Trapezoidal & 0,668 \\
\hline Down Rectangular & 0,634 \\
\hline Down Triangular & 0,626 \\
\hline Down Trapezoidal & 0,619 \\
\hline Trapezoidal & 0,605 \\
\hline
\end{tabular}

\begin{tabular}{|l|r|}
\hline \multirow{2}{*}{ Bentuk daun ekor } & Kecepatan angin \\
\cline { 2 - 2 } & $\mathbf{4 , 8} \mathbf{~ m / s}$ \\
\hline Triangular & $\mathbf{1 , 1 4 0}$ \\
\hline Up Rectangular & 1,039 \\
\hline Rectangular & 1,019 \\
\hline Up Triangular & 0,962 \\
\hline Down Trapezoidal & 0,961 \\
\hline Trapezoidal & 0,913 \\
\hline Up Trapezoidal & 0,881 \\
\hline Down Rectangular & 0,873 \\
\hline Down Triangular & 0,770 \\
\hline
\end{tabular}

\begin{tabular}{|l|r|}
\hline \multirow{2}{*}{ Bentuk daun ekor } & Kecepatan angin \\
\cline { 2 - 2 } & $\mathbf{5 , 2} \mathbf{~} \mathbf{s}$ \\
\hline Trapezoidal & 1,183 \\
\hline Rectangular & 1,118 \\
\hline Down Trapezoidal & 1,113 \\
\hline Triangular & 1,081 \\
\hline Down Rectangular & 1,014 \\
\hline Up Rectangular & 0,994 \\
\hline Up Triangular & 0,971 \\
\hline Down Triangular & 0,935 \\
\hline Up Trapezoidal & 0,921 \\
\hline
\end{tabular}

Tabel 3 menunjukkan bahwa pada panjang batang 0,53 m, pada kecepatan angin 4,3 m/s daya keluaran terbesar terdapat pada bentuk daun ekor jenis Triangular dengan nilai 0,816 watt. Dan daya keluaran terkecil terdapat pada bentuk daun ekor jenis Trapezoidal dengan nilai 0,605 watt. Pada kecepatan angin 4,8 m/s daya keluaran terbesar terdapat pada bentuk daun ekor jenis Triangular dengan nilai 1,140 watt, dan daya keluaran terkecil terdapat pada bentuk daun ekor Down Triangular dengan nilai 0,770 watt. Pada kecepatan angin 5,2 $\mathrm{m} / \mathrm{s}$ daya keluaran terbesar terdapat pada bentuk daun ekor jenis Trapezoidal dengan nilai 1,183 watt, dan 
daya keluaran terkecil terdapat pada bentuk daun ekor jenis Up Trapezoidal dengan nilai 0,921 watt.

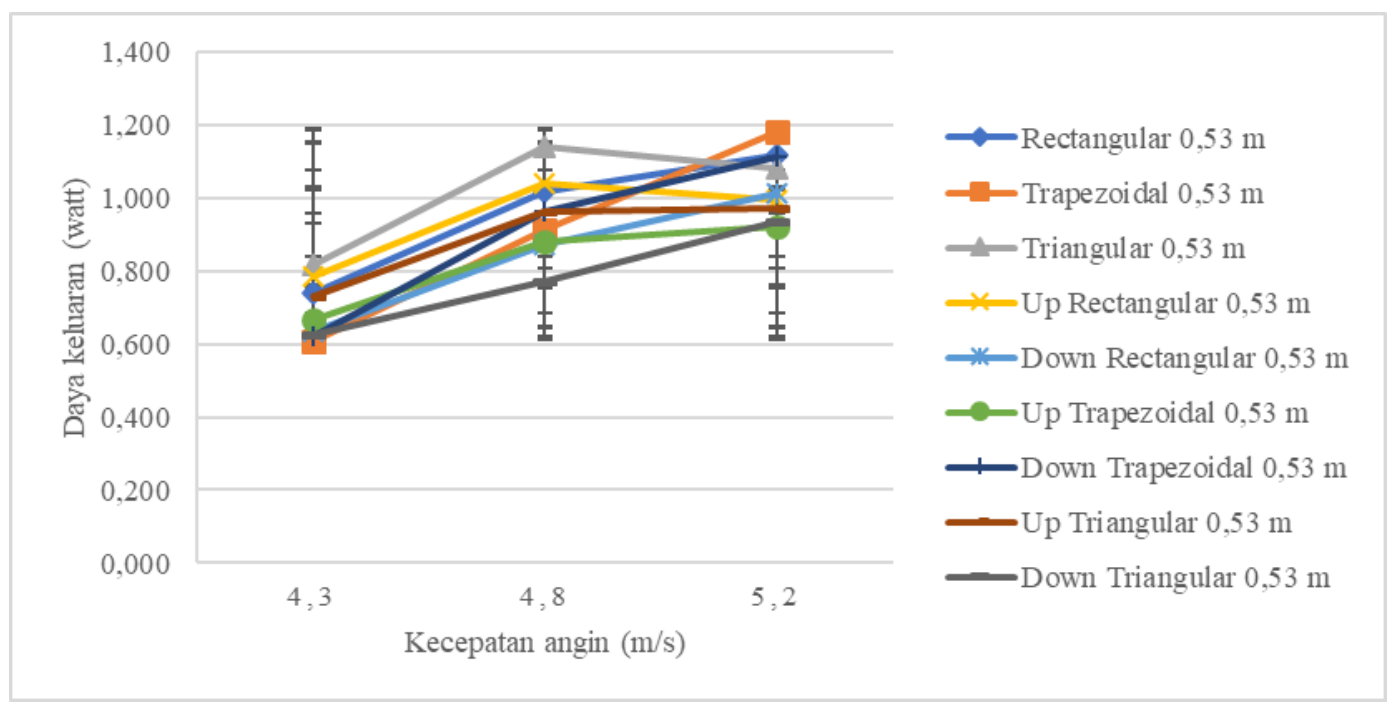

Gambar 7: Hubungan daya keluaran terhadap kecepatan angin $(0,53 \mathrm{~m})$.

Gambar 7 menunjukkan pada panjang batang 0,53 m ini, variasi bentuk daun ekor jenis Rectangular, Trapezoidal, Down Rectangular, Up Trapezoidal, Down Trapezoidal, Up Triangular dan Down Triangular dari kecepatan angin 4,3 m/s ke $5,2 \mathrm{~m} / \mathrm{s}$ terus mengalami kenaikan daya keluaran, sedangkan pada jenis Triangular dan jenis Up Rectangular mengalami penurunan daya keluaran pada kecepatan angin 5,2 m/s. Hal ini terjadi karena adanya faktor dari bentuk daun ekor yang mendapatkan gaya dorong angin, karena untuk bentuk triangular sendiri memiliki keunggulan dalam bentuk, yaitu lebih aerodinamis dan untuk jenis up triangular memliki keunggulan dalam gaya angkatnya yang lebih cepat. Daya terus mengalami kenaikan karena ekor kurang mampu dalam membelokan rotor menjauhi turbin.

Tabel 4: Daya keluaran pada panjang ekor $0,71 \mathrm{~m}$

\begin{tabular}{|l|r|}
\hline \multirow{2}{*}{ Bentuk daun ekor } & Kecepatan angin \\
\cline { 2 - 2 } & $\mathbf{4 , 3} \mathbf{~} / \mathbf{s}$ \\
\hline Triangular & 0,816 \\
\hline Rectangular & 0,753 \\
\hline Up Triangular & 0,720 \\
\hline Up Rectangular & 0,706 \\
\hline Down Triangular & 0,695 \\
\hline Down Trapezoidal & 0,691 \\
\hline Up Trapezoidal & 0,658 \\
\hline Down Rectangular & 0,644 \\
\hline Trapezoidal & 0,642 \\
\hline
\end{tabular}

\begin{tabular}{|l|r|}
\hline \multirow{2}{*}{ Bentuk daun ekor } & Kecepatan angin \\
\cline { 2 - 2 } & $\mathbf{4 , 8} \mathrm{m} / \mathbf{s}$ \\
\hline Triangular & 1,082 \\
\hline Up Rectangular & 1,003 \\
\hline Up Trapezoidal & 0,999 \\
\hline Down Rectangular & 0,966 \\
\hline Rectangular & 0,955 \\
\hline Trapezoidal & 0,948 \\
\hline Down Trapezoidal & 0,940 \\
\hline Down Triangular & 0,814 \\
\hline Up Triangular & 0,735 \\
\hline
\end{tabular}

\begin{tabular}{|l|r|}
\hline \multirow{2}{*}{ Bentuk daun ekor } & Kecepatan angin \\
\cline { 2 - 2 } & $\mathbf{5 , 2} \mathbf{~} / \mathbf{s}$ \\
\hline Rectangular & 1,181 \\
\hline Up Trapezoidal & 1,121 \\
\hline Down Rectangular & 1,092 \\
\hline Trapezoidal & 1,087 \\
\hline Triangular & 1,078 \\
\hline Up Rectangular & 0,980 \\
\hline Down Trapezoidal & 0,886 \\
\hline Down Triangular & 0,827 \\
\hline Up Triangular & 0,742 \\
\hline
\end{tabular}

Tabel 4 menunjukkan bahwa pada panjang batang $0,71 \mathrm{~m}$, pada kecepatan angin 4,3 $\mathrm{m} / \mathrm{s}$ daya keluaran terbesar terdapat pada bentuk daun ekor jenis Triangular dengan nilai 0,816 watt. Dan daya keluaran terkecil terdapat pada bentuk daun ekor jenis Trapezoidal dengan nilai 0,642 watt. Pada kecepatan angin $4,8 \mathrm{~m} / \mathrm{s}$ daya keluaran terbesar terdapat pada bentuk daun ekor jenis Triangular dengan nilai 1,082 watt, dan daya keluaran terkecil terdapat pada bentuk daun ekor jenis Up Triangular dengan nilai 0,735 watt. Pada kecepatan angin 5,2 m/s daya keluaran terbesar terdapat pada bentuk daun ekor jenis Rectangular dengan nilai 1,181 watt, dan daya keluaran terkecil terdapat pada bentuk daun ekor jenis Up Triangular dengan nilai 0,742 watt.

Gambar 8 menunjukkan pada panjang batang 0,71 m ini, variasi bentuk daun ekor jenis Rectangular, Trapezoidal, Down Rectangular, Up Trapezoidal, Up Triangular dan Down Triangular kecepatan angin 4,3 $\mathrm{m} / \mathrm{s}$ ke 5,2 m/s terus mengalami kenaikan daya keluaran, kecuali pada jenis Triangular, Up Rectangular dan Down Trapezoidal mengalami penurunan daya keluaran pada kecepatan angin 5,3 m/s. Pada panjang batang ekor 0,71 $\mathrm{m}$ ini lebih stabil dibandingkan dengan variasi panjang batang ekor lainnya, namun panjang batang 
ekor $0,71 \mathrm{~m}$ ini memiliki titik balik yang terlalu tinggi dari rancangan yaitu pada kecepatan angin $6 \mathrm{~m} / \mathrm{s}$. Variasi daun ekor yang mengalami penurunan daya keluaran pada kecepatan angin 5,2 m/s yaitu Triangular, Up Rectangular dan Down Trapezoidal yang lebih mampu untuk memaksimalkan momen dorong dan momen baliknya.

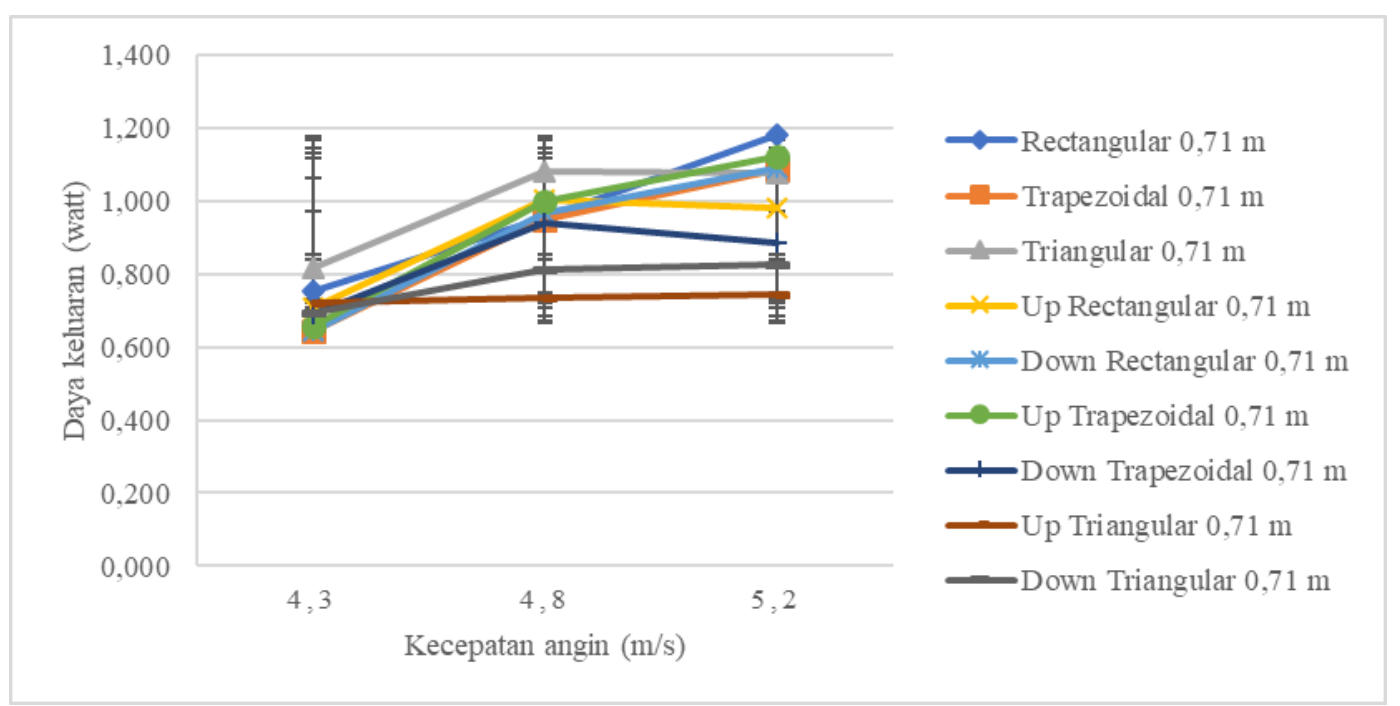

Gambar 8: Hubungan daya keluaran terhadap kecepatan angin $(0,71 \mathrm{~m})$.

Grafik sudut yawing terhadap kecepatan angin untuk variasi bentuk daun ekor berdasarkan panjang batang ekor ditunjukkan sesuai dengan Gambar 12, Gambar 13 dan Gambar 14.

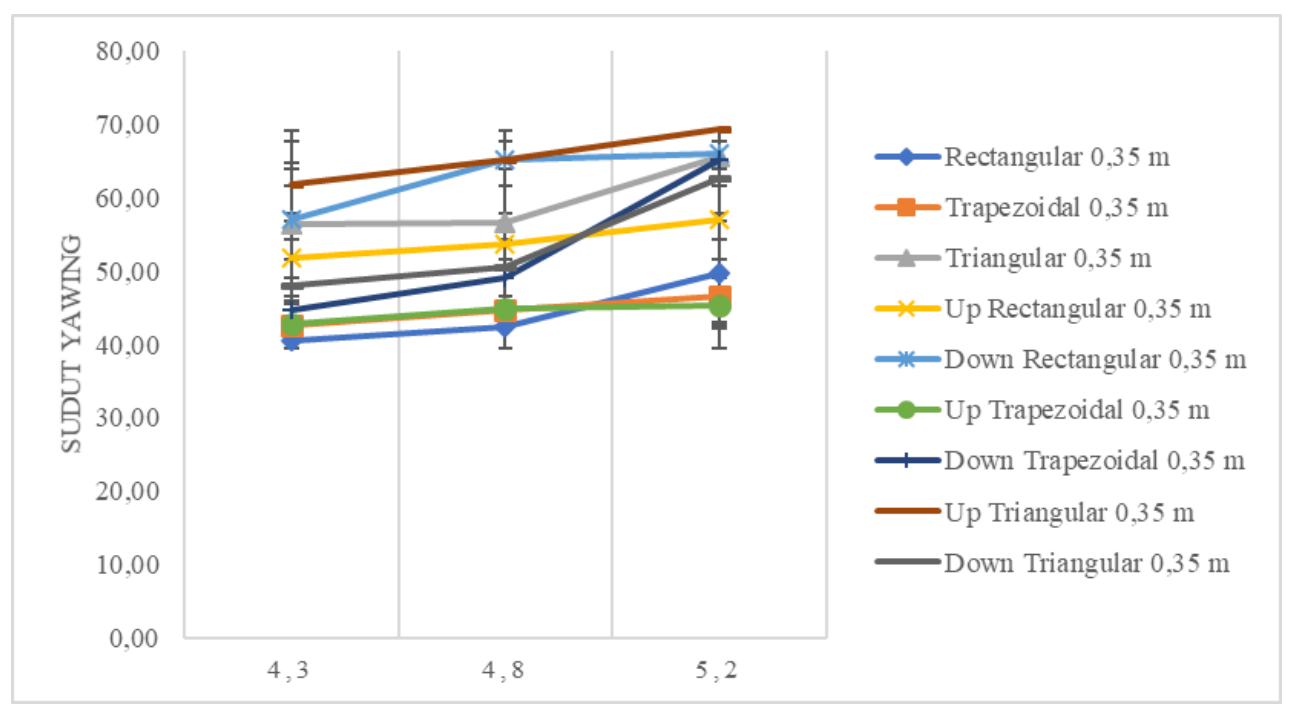

Gambar 9: Sudut yawing terhadap kecepatan angin $(0,35 \mathrm{~m})$

Gambar 9 menunjukkan bahwa pada panjang batang $0,35 \mathrm{~m}$, semua bentuk daun ekor mulai dari Rectangular sampai dengan Down Triangular, sudut yawing yang terbentuk semakin besar seiring dengan kecepatan angin yang bertambah.

Sudut yawing terbesar yang terbentuk pada kecepatan angin 4,3 m/s terdapat pada bentuk daun ekor Up Triangular yaitu 61,73 derajat, dan sudut yawing terkecil pada bentuk daun ekor Rectangular yaitu 40,56 derajat. Pada kecepatan angin 4,8 m/s yang terbesar terdapat pada bentuk daun ekor Down Rectangular yaitu 65,23 derajat, dan sudut yawing terkecil pada bentuk daun ekor Rectangular yaitu 42,40 derajat. Pada kecepatan angin 5,2 m/s yang terbesar terdapat pada bentuk daun ekor Up Triangular yaitu 69,36 derajat, dan sudut yawing terkecil pada bentuk daun ekor Up Trapezoidal yaitu 45,24 derajat.

Gambar 10 menunjukkan bahwa pada panjang batang $0,53 \mathrm{~m}$, semua bentuk daun ekor mulai dari Rectangular sampai dengan Down Triangular, sudut yawing yang terbentuk semakin besar seiring dengan 
kecepatan angin yang bertambah.

Sudut yawing terbesar yang terbentuk pada kecepatan angin $4,3 \mathrm{~m} / \mathrm{s}$ terdapat pada bentuk daun ekor Triangular yaitu 44,17 derajat, dan sudut yawing terkecil pada bentuk daun ekor Up Trapezoidal yaitu 30,88 derajat. Pada kecepatan angin 4,8 m/s yang terbesar terdapat pada bentuk daun ekor Triangular yaitu 52,98 derajat, dan sudut yawing terkecil pada bentuk daun ekor Rectangular yaitu 35,64 derajat. Pada kecepatan angin 5,2 m/s yang terbesar terdapat pada bentuk daun ekor Triangular yaitu 61,84 derajat, dan sudut yawing terkecil pada bentuk daun ekor Up Trapezoidal yaitu 43,65 derajat.

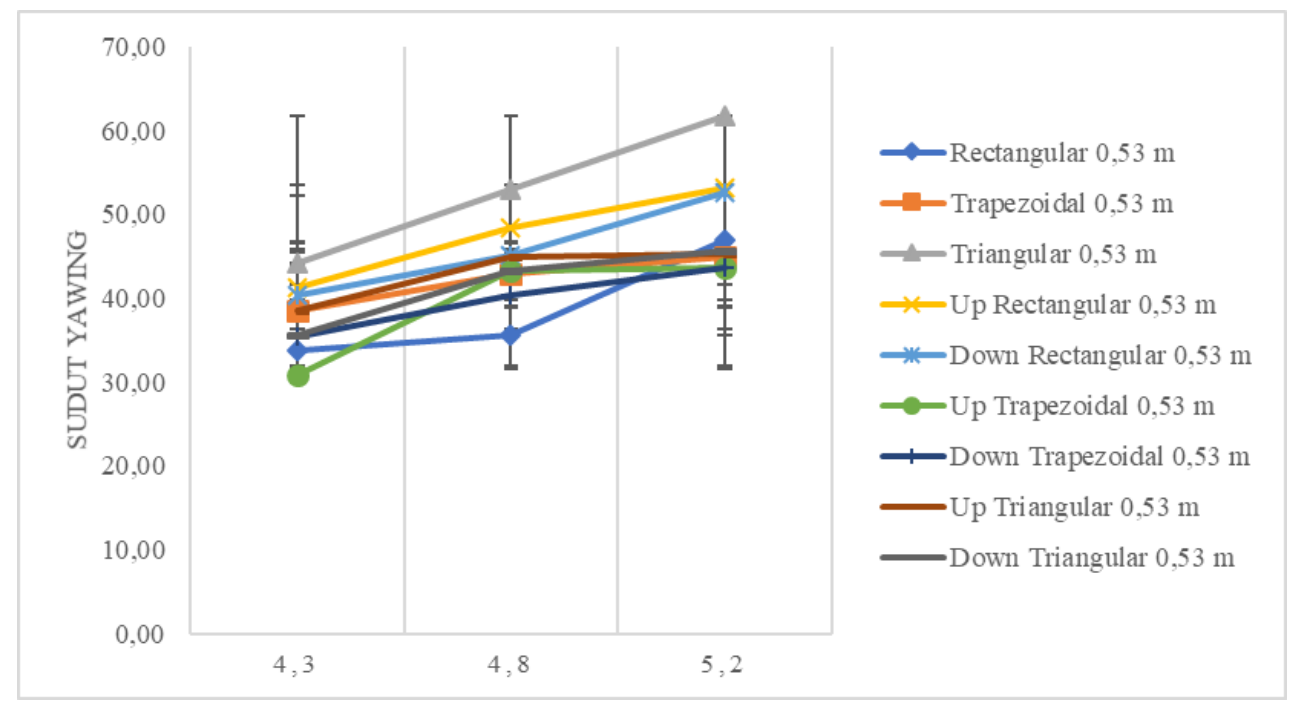

Gambar 10: Sudut yawing terhadap kecepatan angin $(0,53 \mathrm{~m})$

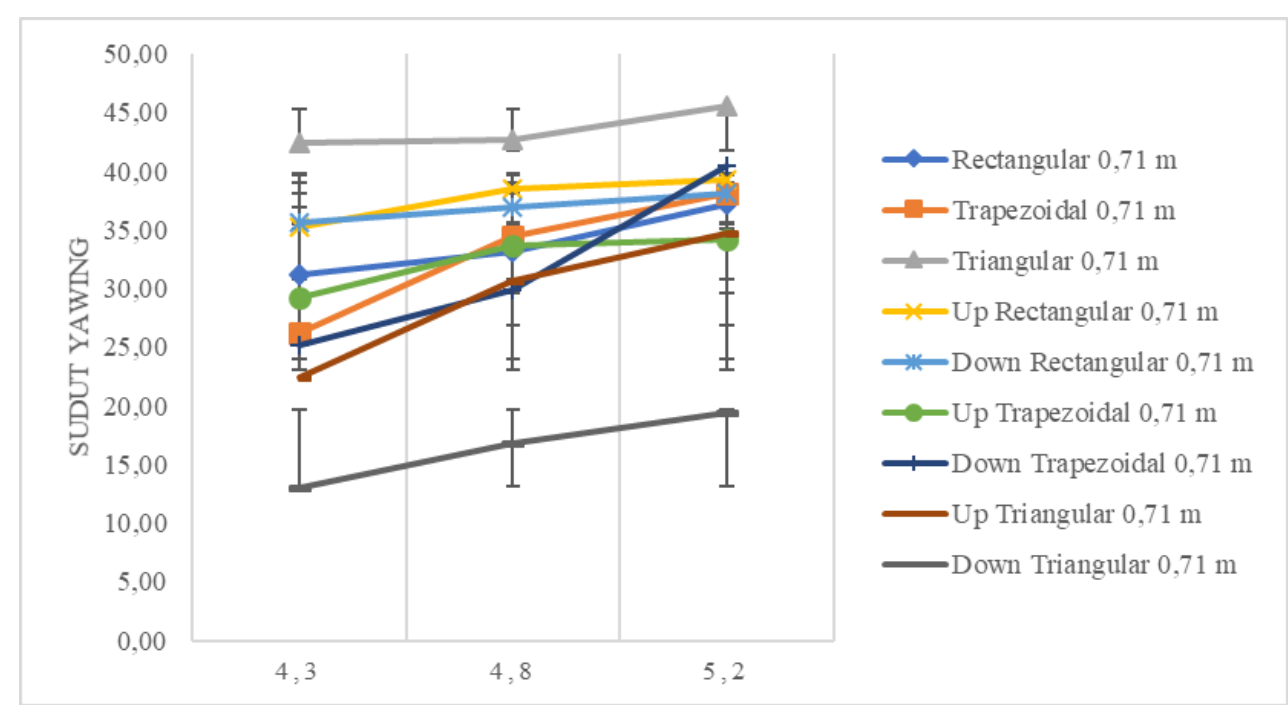

Gambar 11: Sudut yawing terhadap kecepatan angin $(0,71 \mathrm{~m})$

Gambar 11 menunjukkan bahwa pada panjang batang 0,71 m, semua bentuk daun ekor mulai dari Rectangular sampai dengan Down Triangular, sudut yawing yang terbentuk semakin besar seiring dengan kecepatan angin yang bertambah.

Sudut yawing terbesar yang terbentuk pada kecepatan angin $4,3 \mathrm{~m} / \mathrm{s}$ terdapat pada bentuk daun ekor Triangular yaitu 42,39 derajat, dan sudut yawing terkecil pada bentuk daun ekor Down Triangular yaitu 12,94 derajat. Pada kecepatan angin 4,8 m/s yang terbesar terdapat pada bentuk daun ekor Triangular yaitu 42,62 derajat, dan sudut yawing terkecil pada bentuk daun ekor Down Triangular yaitu 16,82 derajat. Pada kecepatan angin 5,2 m/s yang terbesar terdapat pada bentuk daun ekor Triangular yaitu 45,50 derajat, dan sudut yawing terkecil pada bentuk daun ekor Down Triangular yaitu 19,45 derajat. 
Grafik sudut furling terhadap kecepatan angin untuk variasi bentuk daun ekor berdasarkan panjang batang ekor ditunjukkan sesuai dengan Gambar 12, Gambar 13 dan Gambar 14.

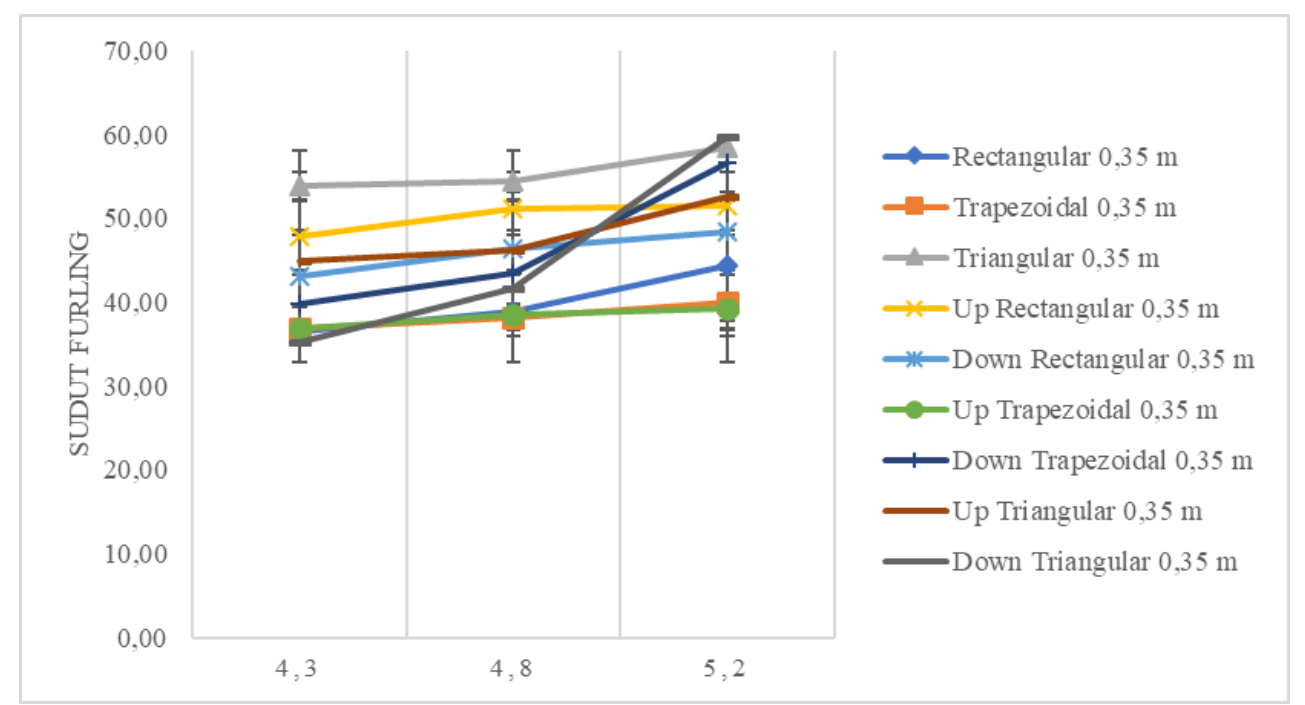

Gambar 12: Sudut furling terhadap kecepatan angin $(0,35 \mathrm{~m})$

Gambar 12 menunjukkan bahwa pada panjang batang 0,35 m, semua bentuk daun ekor mulai dari Rectangular sampai dengan Down Triangular, sudut furling yang terbentuk semakin besar seiring dengan kecepatan angin yang bertambah.

Sudut furling terbesar yang terbentuk pada kecepatan angin $4,3 \mathrm{~m} / \mathrm{s}$ terdapat pada bentuk daun ekor Triangular yaitu 53,94 derajat, dan sudut furling terkecil pada bentuk daun ekor Down Triangular yaitu 35,17 derajat. Pada kecepatan angin 4,8 m/s yang terbesar terdapat pada bentuk daun ekor Triangular yaitu 54,44 derajat, dan sudut furling terkecil pada bentuk daun ekor Trapezoidal yaitu 38,10 derajat. Pada kecepatan angin 5,2 m/s yang terbesar terdapat pada bentuk daun ekor Down Triangular yaitu 59,65 derajat, dan sudut furling terkecil pada bentuk daun ekor Up Trapezoidal yaitu 39,20 derajat.

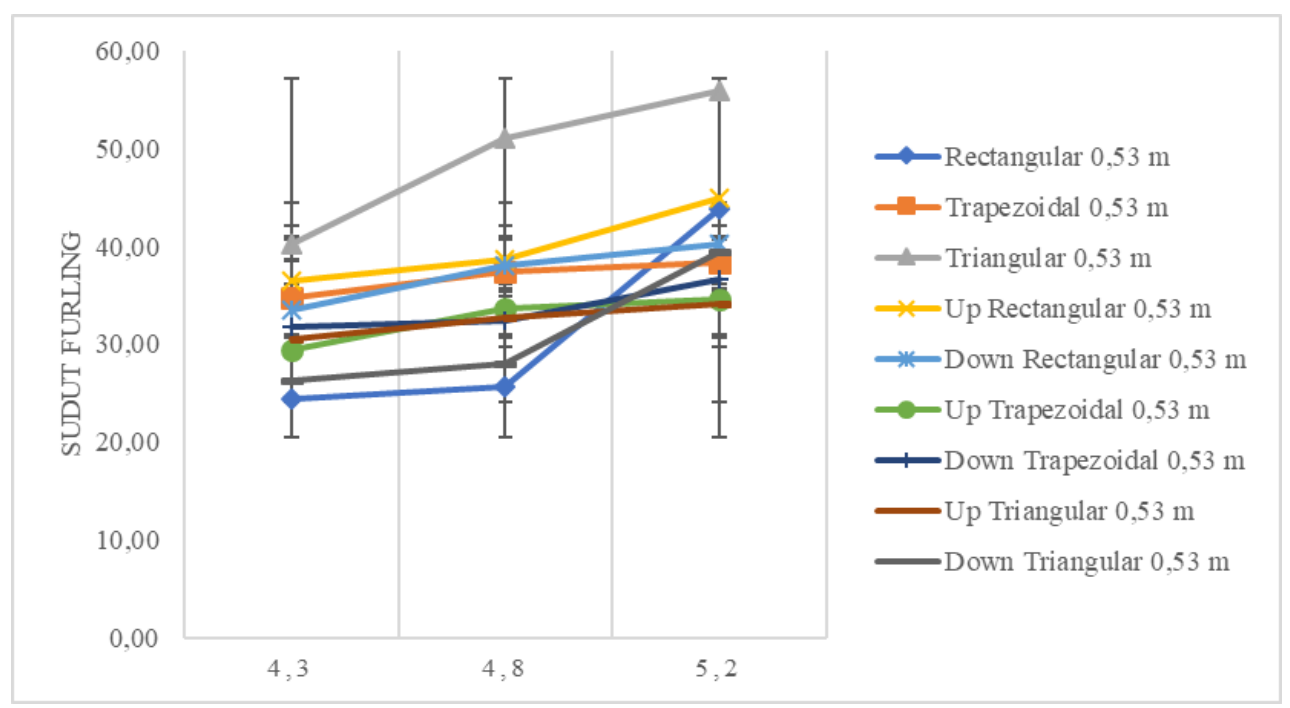

Gambar 13: Sudut furling terhadap kecepatan angin $(0,53 \mathrm{~m})$

Gambar 13 menunjukkan bahwa pada panjang batang 0,53 m, semua bentuk daun ekor mulai dari Rectangular sampai dengan Down Triangular, sudut furling yang terbentuk semakin besar seiring dengan kecepatan angin yang bertambah. 
Sudut furling terbesar yang terbentuk pada kecepatan angin $4,3 \mathrm{~m} / \mathrm{s}$ terdapat pada bentuk daun ekor Triangular yaitu 40,16 derajat, dan sudut furling terkecil pada bentuk daun ekor Rectangular yaitu 24,42 derajat. Pada kecepatan angin 4,8 m/s yang terbesar terdapat pada bentuk daun ekor Triangular yaitu 50,99 derajat, dan sudut furling terkecil pada bentuk daun ekor Rectangular yaitu 25,67 derajat. Pada kecepatan angin 5,2 m/s yang terbesar terdapat pada bentuk daun ekor Triangular yaitu 55,93 derajat, dan sudut furling terkecil pada bentuk daun ekor Up Triangular yaitu 34,04 derajat.

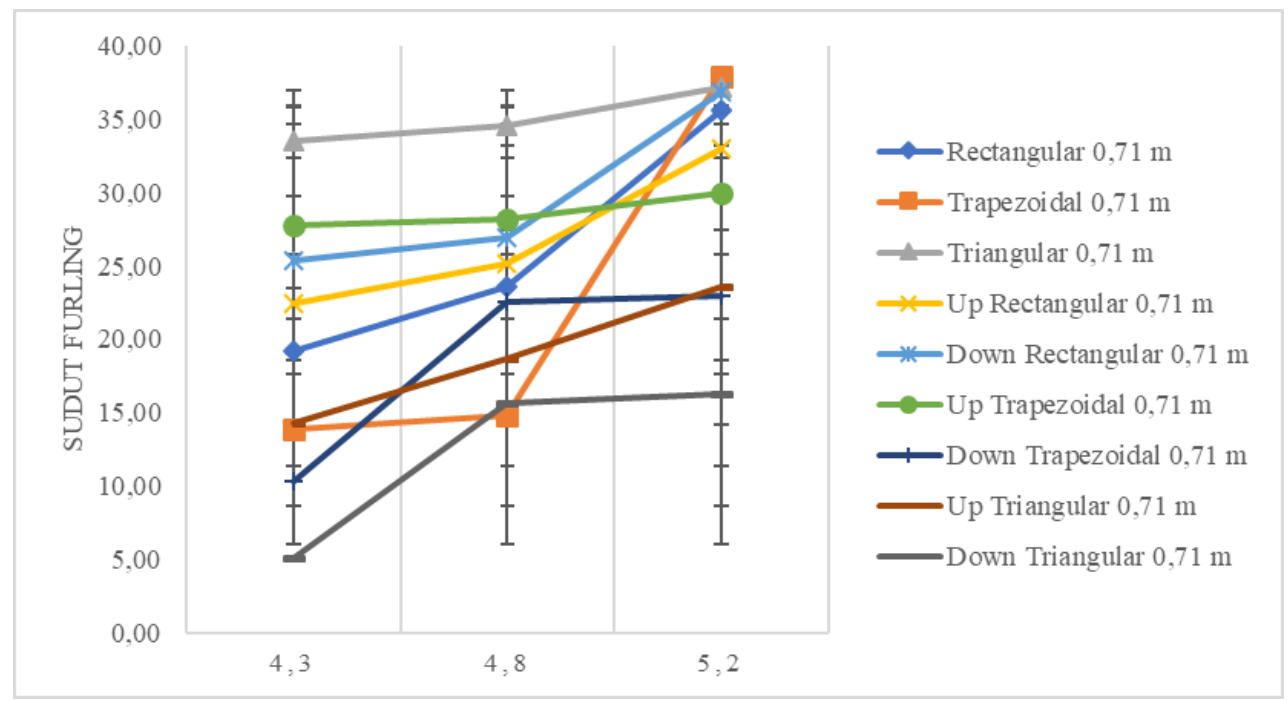

Gambar 14: Sudut furling terhadap kecepatan angin $(0,71 \mathrm{~m})$

Gambar 14 menunjukkan bahwa pada panjang batang 0,71 m, semua bentuk daun ekor mulai dari Rectangular sampai dengan Down Triangular, sudut furling yang terbentuk semakin besar seiring dengan kecepatan angin yang bertambah.

Sudut furling terbesar yang terbentuk pada kecepatan angin $4,3 \mathrm{~m} / \mathrm{s}$ terdapat pada bentuk daun ekor Triangular yaitu 33,56 derajat, dan sudut furling terkecil pada bentuk daun ekor Down Triangular yaitu 5,05 derajat. Pada kecepatan angin 4,8 m/s yang terbesar terdapat pada bentuk daun ekor Triangular yaitu 34,57 derajat, dan sudut furling terkecil pada bentuk daun ekor Trapezoidal yaitu 14,81 derajat. Pada kecepatan angin $5,2 \mathrm{~m} / \mathrm{s}$ yang terbesar terdapat pada bentuk daun ekor Trapezoidal yaitu 37,88 derajat, dan sudut furling terkecil pada bentuk daun ekor Down Triangular yaitu 16,28 derajat.

\subsection{Stabilitas Ekor}

Pada saat pengujian dan pengambilan data, rakitan ekor yang dirancang mampu menyesuaikan kemampuan sudu. Rancangan batas kecepatan angin yaitu $5 \mathrm{~m} / \mathrm{s}$. Pada kondisi diatas kecepatan angin rancangan, turbin akan membentuk sudut furling dan yawing yang akan berakibat pada berkurangnya penangkapan angin untuk menjaga keamanan dari sudu dan turbin itu sendiri. Pada saat kecepatan angin kembali normal yaitu dibawah kecepatan rancangan, rakitan ekor ini mampu kembali mengarahkan turbin kembali menghadap angin dan turbin kembali mampu menghasilkan daya keluaran.

Pada panjang ekor terpendek $(0,35 \mathrm{~m})$ menunjukkan fenomena yang kurang stabil karena faktor moment thrust pada sirip ekor yang tidak diimbangi dengan momen furling dari ekor, sehingga pada kecepatan angin rendah lebih cenderung menunjukkan gerakan ekor yang tidak stabil yang mempengaruhi stabilitas dari turbin angin. Pada panjang ekor terpanjang $(0,71 \mathrm{~m})$ menunjukan fenomena yang sebaliknya, yaitu lebih stabil karena moment thrust mampu mengimbangi momen furling pada sirip ekor. Namun memiliki titik balik yang tinggi yaitu pada kecepatan angin $6 \mathrm{~m} / \mathrm{s}$ (diatas rancangan).

\section{KESIMPULAN}

Berdasarkan hasil penelitian menunjukkan bahwa:

1. Semakin panjang ukuran dari panjang batang ekor maka akan semakin kecil sudut yawing maupun furling yang dibentuk.

2. Daya maksimum yang mampu dihasilkan oleh turbin angin pada kecepatan angin $4,3 \mathrm{~m} / \mathrm{s}$ yaitu pada bentuk daun ekor Triangular dengan panjang batang ekor 0,35 m dengan nilai 0,991 watt. Pada kecepatan 
angin 4,8 m/s yaitu pada bentuk daun ekor Triangular dengan panjang batang ekor $0,53 \mathrm{~m}$ dengan nilai 1,140 watt. Pada kecepatan angin $5,2 \mathrm{~m} / \mathrm{s}$ yaitu pada bentuk daun ekor Trapezoidal dengan panjang batang ekor $0,53 \mathrm{~m}$ dengan nilai 1,183 watt.

3. Mekanisme furling yang sudah dirancang pada kecepatan angin $5 \mathrm{~m} / \mathrm{s}$ bekerja dengan baik, namun pada kecepatan $4,3 \mathrm{~m} / \mathrm{s}$ sudut yawing dan furling sudah bekerja dengan membentuk sudut yawing tertinggi pada bentuk daun ekor Up Triangular dengan panjang batang ekor $0,35 \mathrm{~m}$ yaitu 61,73 derajat, dan sudut furling tertinggi pada bentuk daun ekor Triangular dengan panjang batang ekor 0,35 m yaitu 53,94 derajat.

4. Konfigurasi yang paling stabil atau yang paling ideal berdasarkan hasil penelitian untuk turbin ini adalah jenis Triangular dengan panjang batang ekor $0,53 \mathrm{~m}$, daya yang mampu dihasilkan yaitu 0,816 watt $(4,3$ $\mathrm{m} / \mathrm{s}), 1,140$ watt $(4,8 \mathrm{~m} / \mathrm{s})$ dan 1,081 watt $(5,2 \mathrm{~m} / \mathrm{s})$.

\section{DAFTAR PUSTAKA}

[1] HEMAMI, A., Wind Turbine Technology, Clifton Park, N.Y., CENGAGE Learning. 2012.

[2] DEN, Outlook Energy Indonesia 2016, Jakarta Selatan, https://www.den.go.id, 2016.

[3] ARINALDO, D., ADIATMA, J. C., SIMAMORA, P., Indonesia Clean Energy Outlook Reviewing 2018, Outlooking 2019, In: IESR 1-38, Institute for Essential Services Reform, Jakarta Selatan, 2018.

[4] ULLY, D. N., SOEPARMAN, S., HAMIDI, N., "Pengaruh Pemasangan Sudu Pengarah dan Variasi Jumlah Sudu Rotor terhadap Performance Turbin Angin Savonius", Jurnal Rekayasa Mesin, Vol. 5, No. 2, pp. 127-134, 2014.

[5] MANWELL, J. F., MCGOWAN, J. G., ROGERS, A. L., Wind Energy Explained Theory, Design and Application, Second Edition, West Sussex, U.K., John Willey \& Sons Ltd. Publication, 2009.

[6] PIGGOTT, H., Windpower Workshop Building Your Own Turbine, Centre for Alternative Technology Publications, 1997.

[7] NIKHIL, C. R., SANDIP, A. K., "Effect of Tail Shape on Yawing Performance of Micro Wind Turbine", International Journal of Energy and Power Engineering, Vol. 4, No. 5-1, 38-42, August 2015.

[8] SINGAMSITTY, V., ZHOU, H., "Tail Shape Design of Boat Wind Turbines", International Journal of Engineering Research \& Technology, Vol. 6 Issue 03, 582-587, March 2017.

[9] ATMADI, S., FITROH, A. J., "Rancangan Sistem Orientasi Ekor Turbin Angin $50 \mathrm{kW",} \mathrm{Jurnal}$ LAPAN, vol. 5, no. 2, pp. 113-117, Desember 2007.

[10] SUANDI, A., PRAMUDIONO, L., SUPARDI, N. I., PUSPAWAN, A., "Kaji Karakteristik Mekanik Furling Control dengan Sudut Ekor $20^{\circ}$ pada Kincir Angin Skala Mikro", Jurnal Ilmiah Teknik Mesin Rekayasa Mekanik, Vol. 1 No. 2, pp. 21-26. Oktober 2017.

[11] PIGGOTT, H., How to Build a Wind Turbine Axial Flux Alternator Windmill Plans 8 Foot and 4 Foot Diameter Machines, U.K., https://www.scoraigwind.com, 2003.

[12] AUDIERNE, E., ELIZONDO, J., BERGAMI, L., IBARRA, H., PROBST, O., "Analysis of the Furling Behavior of Small Wind Turbines", Applied Energy, 2278-2292. Jan. 2010.

[13] MULJADI, E., FORSYTH, T., BUTTERFIELD, C. P., Soft-Stall Control versus Furling Control for Small Wind Turbine Power Regulation, In: Report NREL/CP-500-25100, National Renewable Energy Laboratory, Bakersfield, C.A., 1998.

[14] SURYANA, Metodologi Penelitian. Bandung, Universitas Pendidikan Indonesia, 2010.

[15] SUANDI, A., PRAMUDIONO, L., SUPARDI, N. I., "Perancangan Mekanisme Furling Control untuk Kincir Angin Skala Mikro", Jurnal Teknosia, Vol. III, No. 1, 47-59. Maret 2017. 